\title{
Efficiency measurement of basic service delivery at South African district and local municipalities
}

\author{
$G$ van der Westhuizen and B Dollery*
}

\begin{abstract}
South Africa has experienced immense changes in the postapartheid era and coordinated local public policy has sought to expand and improve the level of basic services provided to previously disadvantaged people. Local government has played a pivotal role in this process and has been subjected to intense reform in an effort to enhance its effectiveness and broaden its range of activities. While a number of scholars have examined the administrative, political and social dimensions of the local government reform program, little attention has focused on the economic efficiency of service delivery. This paper seeks to remedy this neglect by evaluating the productive efficiency with which municipal councils have delivered electricity, domestic waste removal, sanitation and water in line with their new responsibilities using Data Envelopment Analysis (DEA) techniques applied to cross-sectional data covering the period 2006/2007 for 231 local municipalities and 46 district municipalities.
\end{abstract}

Keywords: Efficiency; local government; local service delivery; South Africa

Disciplines: Economics, Public Management and Administration, Management Sciences.

\section{Introduction}

Local government systems across the world have come under intense scrutiny over the past two decades. A good deal of concern by policy makers has been expressed over various aspects of local government, including its operational efficiency. This has seen a wave of reform in many local government jurisdictions which has encompassed almost all dimensions of local government structure and function (Dollery, et al., 2008). South African local government has not been immune to these international trends and it too has been subjected to vigorous change. Indeed, few local government systems have undergone a greater degree of transformation (Cameron, 2001; Visser, 2001).

The dramatic nature of local government reform in South Africa has its roots in the apartheid legacy that

* Brian Dollery is Professor of Economics \& Director of the UNE Centre for Local Government, School of Business, Economics and Public Policy University of New, England Armidale NSW 2351 Australia. Email: bdollery@une.edu.au. Gert van der Westhuizen is Professor of Economics, School of Economic Sciences, North-West University, Vaal Campus, Vanderbijlpark, South Africa. E-mail: gvdwesthuizen@absamail.co.za 
confronted policy makers in the first post-apartheid administration. This legacy included a high degree of economic, spatial and social inequality between the different population groups, together with a 'dual economy' divided along racial lines, and segregated urban areas. Post-apartheid policy makers responded with a range of measures aimed at addressing these inequalities across the entire gamut of economic and social indicators. The most important of these measures consisted of the 1994 Reconstruction and Development Programme (RDP), which sought to coordinate the efforts of central, provincial and local governments into an integrated national whole (Lester, et al, 2000).

The RDP placed great emphasis on the role of local government in this process based on the premise that

\begin{abstract}
the democratic government will reduce the burden of implementation which falls upon its shoulders through the appropriate allocation of powers and responsibilities to lower levels of government (African National Congress, 1994, p.140).
\end{abstract}

This emphasis was given sharper focus in the White Paper on Local Government, which held that local government must co-operate with local communities

to find sustainable ways to meet their needs and improve the quality of their lives (Republic of South Africa, 1998, p.17).

The notion of 'developmental local government' thus grew out of the perception that the role of local government in South Africa should expand decisively from its traditional narrow concentration on 'services to property' to embrace local economic development and local economic growth as well as the conditions that stimulate these elements of national development ( $\mathrm{Nel}$ and Binns, 2002).

The White Paper on Local Government (Republic of South Africa, 1998) set out four key aims for 'developmental local government. In the first place, the provision of a basic level of household services, especially electricity, sewerage and water, to households without these services, should take priority. Secondly, municipalities should seek to ameliorate the 'spatial legacy of apartheid separation' through the integration of previously segregated urban areas. Thirdly, local economic development should be stimulated through local economic growth and local job creation. Finally, 'community empowerment and redistribution' should be addressed.

While these objectives are certainly laudable in the context of post-apartheid South African society, striven by striking racial inequalities, they placed a massive burden on a municipal system that had previously confined its activities to a narrow range of local services. This burden was exacerbated by an acute lack of local government capacity, especially in terms of administrative and technical skills (Buthelezi and Dollery, 2004; Dollery, et al, 2005), as well as very weak financial compliance management (Dollery and Graves, 2009) and chronic funding shortages (Bahl and Smoke, 2003) - problems also apparent at higher tiers of government in South Africa (Dollery, 2004; Dollery and Snowball, 2003). In essence, the problem of local government incapacity seems to derive mainly from a lack of skilled human resources in South African local government to perform its newly expanded responsibilities. Against this background, there is an obvious need to assess the progress made by local government to achieve its new objectives. Some scholarly attention has already been at this important aspect of the reform process (see, for instance, 
Macdonald and Pape, 2002 and Miraftab, 2004). However, to date there has been no work on evaluating econometrically the efficiency of local government service delivery. The present paper thus seeks to address this neglected question by focusing on the first of the quadrilateral suit of policy objectives set out in White Paper on Local Government (Republic of South Africa, 1998). Accordingly, we assess the economic efficiency with which municipal councils have delivered electricity, domestic waste removal, sanitation and water in line with their RDP responsibilities using DEA techniques applied to cross-sectional data covering the period 2006/2007 for 231 local municipalities and 46 district municipalities.

The paper is divided into four main parts. Section 2 provides a synoptic description of the service delivery responsibilities of district municipalities and local municipalities in the South African local government milieu. Section 3 briefly outlines the theory of local government efficiency analysis and the empirical literature that has developed around it. Section 4 sets out the data sources and models employed in the analysis. Section 5 considers the results obtained from the estimations. The paper ends with some brief concluding comments in section 6 .

\section{South African local government service delivery}

In common with its counterparts in Australia and New Zealand, South African local government has traditionally provided a rather narrow range of 'services to property' (Graves and Dollery, 2009). However, in line with the White Paper on Local Government and the RDP aims, the role of municipalities was rapidly expanded to include a much broader array of service objectives.

In terms of its structure, South African local government is sub-divided into three basic categories; metropolitan municipalities, district municipalities and local municipalities. Metropolitan municipalities have municipal executive and legislative authority in their respective local government areas which embrace the major urban concentrations of Cape Town, Durban, East Rand, Johannesburg, Pretoria and Port Elizabeth. By contrast, district municipalities have municipal executive and legislative authority over significant spatial areas, with primary responsibility for district-wide planning and capacity-building. Within the local jurisdiction of each district municipality there are typically several individual local municipalities which share their municipal authority with the district municipality. In essence, district municipalities administer and make rules for a district, which includes more than one local municipality. South Africa has a total of 284 municipalities in these three categories combined (Atkinson, 2002).

The intended purpose of district municipalities and local municipalities sharing responsibility for local government in their given areas is to ensure that all communities, particularly historically disadvantaged communities, have equal access to resources and services. Since district municipalities usually cover both relatively affluent and relatively poor concentrations of people, consequent upon the apartheid legacy, this facilitates 'cross-subsidisation', enabling local municipalities without adequate administrative, financial and technical capacity to provide basic services to their historically disadvantaged communities. In addition, the system provides scope for shared services between local municipalities which can generate economics of scale and scope and attendant cost reductions.

The functions of district municipalities are manifold. From the perspective of local service delivery, district 
municipalities inter alia must plan for development for the district municipality as a whole; provide bulk supply of water that affects a large proportion of the municipalities in the district; supply bulk electricity; provide municipal health services for the whole municipalities in the district; ensure bulk sewerage purification works and main sewerage disposal; provide waste disposal sites for the whole district; provide municipal roads and storm water drainage for the district municipality area; provide municipal public works; ensure street lighting; and provide municipal parks and recreation facilities.

In the present context, financial management represents an important aspect of the overall South African local government reform process. In this regard, the National Treasury has played a pivotal role in the introduction of financial management reforms across local government since 1996. The legislative cornerstone of the municipal reform process has been the Municipal Finance Management Act, 56 of 2003 (MFMA), supported by the annual Division of Revenue Act. This legislation has been aligned with other important local government enactments, such as the Structures Act, Systems Act, Property Rates Act, to form a coherent package.

The prime objective of the National Treasury in the local government realm has been to secure sound and sustainable management of the financial affairs of local government. This has required the development of a coherent approach to improve the delivery of services to local communities. The National Treasury has implemented a strategy of financial and technical support for local government based around the MFMA, including conditional grants, subsidies, technical guidelines, policy advice and the placement of international advisors with various municipalities (Dollery and Graves, 2009). This strategy took into account the vastly different levels of capacity of the different municipalities for implementing the reforms. It also prescribed requirements for institutional strengthening, municipal capacity building and improving municipal consultation, reporting, transparency and accountability. In sum, the MFMA aims to modernise budget, accounting and financial management practices by placing local government finances on a sustainable footing in order to maximise the capacity of municipalities to deliver services to communities.

\section{Local government efficiency measurement}

Ongoing local government reform around the world has led increasing sophisticated attempts to measure the effects of reform programs. This has given rise to a growing theoretical and empirical literature on local government efficiency measurement (Worthington and Dollery, 2000). Economic efficiency has various dimensions, including allocative efficiency, productive efficiency, dynamic efficiency, scale efficiency and scope efficiency. Technical or productive efficiency refers to the use of resources in the technologically most efficient manner in order to obtain the maximum possible output(s) from a given set of inputs. When productive efficiency is determined in monetary terms, it is sometimes known as cost efficiency.

Several features of local government service delivery have made it difficult to develop accurate measures of productive efficiency, especially for benchmarking and comparative performance measurement. These features include (a) multiple inputs and outputs in service delivery (b) problems in estimating the costs of service delivery (c) the existence of different stakeholders with competing needs impedes efficiency improvement, and (c) 'non-discretionary' factors beyond the control of local government (Worthington and Dollery, 2002). 
Despite these difficulties, economists have applied five different approaches to the analysis of local public sector efficiency (Worthington, 2001): Least squares econometric production models; the deterministic frontier approach; the stochastic frontier approach; the fee-disposal hull approach; and DEA. DEA is often used to measure the relative efficiency (or productivity) of organisations in the same industry, such as municipalities. DEA is typically the preferred measure of relative efficiency for complex organizations in complex environments because it readily lends itself to the analysis of multiple output organisations, especially where binding constraints affect the behaviour of the organisations in question. In essence, DEA combines all the input and output information on the local municipality into a single measure of productive efficiency that lies between zero (i.e. a completely inefficient municipality) and unity (i.e. a completely efficient municipality). DEA is thus an application of linear programming that can be used to measure the relative efficiency of organisations with the same goals and objectives.

The empirical measurement of allocative, cost, productive and scale efficiencies involves the estimation of production frontiers. DEA effectively estimates the frontier by finding a set of linear estimates that bound (or envelop) the observed data. Measuring productive efficiencies using DEA requires data on output and input quantities whereas measuring allocative and cost efficiencies also needs data on input prices. Outputs measures used in DEA studies of local government services have typically used only quantitative measures, and often 'non-discretionary' quantitative output measures like the number of residents receiving garbage collection. Worthington and Dollery (2000) provide a detailed discussion of DEA and other frontier techniques for the measurement of economic efficiency in local government, whereas Worthington (2001) has summarised the empirical literature on local government.

\section{Data and models}

Securing adequate and satisfactory data on South African local government represents a formidable challenge to all researchers in the area (Bahl and Smoke, 2003). After repeated unsuccessful requests to individual local municipalities and individual district municipalities to supply relevant data that could be used to estimate the efficiency of various local services, to which only two municipalities responded positively, we were obliged to use data published by the Demarcation Board of South Africa (2006/2007). This data comprised inter alia total number of households, RDP water, RDP sanitation, RDP electricity, $\mathrm{RDP}$ refuse removal, the number of staff, various types of income that can be aggregated as total operating income and staff costs. The number of households, RDP water, sanitation electricity and refuse removal are derived from the 2001 national census. This was adjusted to represent number of households in 2006/2007 using the population growth rate in proportion to the estimates of the population per province (Statistics SA, 2008). The total number of households was checked using a regression equation with an independent variable given as the total number of households for 2006/2007 and the dependent variable the number of households serviced for each type of service rendered.

The data used for the analysis in this paper represent budget data for the relevant variables used. In common with all efficiency measurement exercises, the quality of the data obviously determines the quality of the results obtained from the analysis. This raises various potential problems in the present context. For instance, an improved municipal budgeting process may change efficiency results without any corresponding real change in local services actually delivered. However, there is some evidence which suggests that this may not be a significant problem in the time period under review (Dollery and Graves, 
2009). In any event, cross-sectional data covering the fiscal year 2006/2007 were employed, which included 231 local municipalities and 46 district municipalities.

A DEA was performed using as output variables the total number of households receiving RDP water, RDP sanitation RDP electricity and RDP refuse removal. For input variables, the Rand value of staff costs and total operational income were used. Total operational income was employed as an input since this represent the aggregate funds to deliver the various local services under review; it incorporates the rand value of rates income, services income and government grants.

\section{Discussion of results}

The software package DEAP Version 2.1 developed by Coelli (1996) is 'purpose-built' to solve the DEA problem in efficiency estimation procedures and typically forms the methodological basis for many local government efficiency measurement exercises. Accordingly, it has been used for the estimations reported in this paper to generate estimates of technical efficiency and scale efficiency. The efficiency estimates are executed under constant returns to scale (CRSTE) and variable returns to scale (VRSTE); they embrace output-orientated as well as input-orientated approaches. The output-orientated approach applies to a situation in which a given district municipality seeks to maximise the output with a given set of inputs, whereas an input-orientated approach applies to the situation in which the district municipality seeks to deliver the desired output with the minimum input. In the present context, discussion of our results will primarily concentrate on the efficiency estimates under variable returns to scale (VRS). Following Coelli et al (1998:150), the use of the constant returns to scale (CRS) specification when not all firms are operating at the optimal scale results in measures of relative efficiency (TE) which are confounded by scale efficiencies (SE). The use of VRS specification thus permits the calculation of TE devoid of these SE effects.

The relative efficiency estimates for the district municipalities in the country are depicted in Table 1.

Table 1: Relative Efficiency Estimates for District Municipalities

\begin{tabular}{|c|c|c|c|c|c|c|c|c|}
\hline & \multicolumn{5}{|c|}{ Output-orientated } & \multicolumn{4}{c|}{ Input-orientated } \\
\hline District & CRSTE & VRSTE & SCALE & RETURN & CRSTE & VRSTE & SCALE & RETURN \\
\hline 1 & 0.071 & 0.370 & 0.193 & drs & 0.071 & 0.108 & 0.665 & irs \\
\hline 2 & 0.118 & 0.743 & 0.158 & drs & 0.118 & 0.126 & 0.936 & drs \\
\hline 3 & 0.076 & 0.301 & 0.254 & drs & 0.076 & 0.158 & 0.483 & irs \\
\hline 4 & 0.095 & 0.609 & 0.155 & drs & 0.095 & 0.107 & 0.883 & drs \\
\hline 5 & 0.043 & 0.087 & 0.492 & drs & 0.043 & 0.266 & 0.160 & irs \\
\hline 6 & 0.102 & 0.135 & 0.759 & drs & 0.102 & 0.352 & 0.291 & irs \\
\hline 7 & 0.106 & 0.185 & 0.574 & drs & 0.106 & 0.348 & 0.306 & irs \\
\hline 8 & 0.223 & 0.365 & 0.610 & drs & 0.223 & 0.265 & 0.840 & irs \\
\hline 9 & 0.221 & 0.429 & 0.516 & drs & 0.221 & 0.451 & 0.491 & irs \\
\hline 10 & 0.108 & 0.411 & 0.262 & drs & 0.108 & 0.212 & 0.509 & irs \\
\hline
\end{tabular}




\begin{tabular}{|c|c|c|c|c|c|c|c|c|}
\hline & \multicolumn{4}{|c|}{ Output-orientated } & \multicolumn{4}{|c|}{ Input-orientated } \\
\hline District & Crste & Vrste & Scale & Return & Crste & Vrste & Scale & Return \\
\hline 11 & 0.222 & 1.000 & 0.222 & drs & 0.222 & 1.000 & 0.222 & drs \\
\hline 12 & 0.134 & 0.449 & 0.299 & drs & 0.134 & 0.174 & 0.773 & irs \\
\hline 13 & 0.045 & 0.185 & 0.245 & drs & 0.045 & 0.128 & 0.355 & irs \\
\hline 14 & 0.075 & 0.399 & 0.187 & drs & 0.075 & 0.110 & 0.680 & irs \\
\hline 15 & 1.000 & 1.000 & 1.000 & - & 1.000 & 1.000 & 1.000 & - \\
\hline 16 & 0.602 & 0.913 & 0.660 & drs & 0.602 & 0.684 & 0.881 & drs \\
\hline 17 & 0.614 & 0.825 & 0.745 & drs & 0.614 & 0.696 & 0.882 & irs \\
\hline 18 & 0.776 & 0.840 & 0.924 & drs & 0.776 & 0.803 & 0.967 & drs \\
\hline 19 & 0.648 & 0.765 & 0.847 & irs & 0.648 & 0.963 & 0.673 & irs \\
\hline 20 & 0.045 & 0.342 & 0.132 & drs & 0.045 & 0.081 & 0.561 & irs \\
\hline 21 & 0.279 & 0.840 & 0.332 & drs & 0.279 & 0.332 & 0.841 & drs \\
\hline 22 & 0.087 & 0.363 & 0.239 & drs & 0.087 & 0.093 & 0.929 & irs \\
\hline 23 & 0.230 & 1.000 & 0.230 & irs & 0.230 & 1.000 & 0.230 & irs \\
\hline 24 & 0.506 & 1.000 & 0.506 & irs & 0.506 & 1.000 & 0.506 & irs \\
\hline 25 & 0.089 & 0.318 & 0.280 & drs & 0.089 & 0.223 & 0.400 & irs \\
\hline 26 & 0.084 & 0.188 & 0.445 & drs & 0.084 & 0.348 & 0.240 & irs \\
\hline 27 & 0.141 & 0.462 & 0.305 & drs & 0.141 & 0.223 & 0.631 & irs \\
\hline 28 & 0.071 & 0.309 & 0.228 & drs & 0.071 & 0.102 & 0.691 & irs \\
\hline 29 & 0.615 & 0.848 & 0.725 & $\mathrm{drs}$ & 0.615 & 0.675 & 0.911 & irs \\
\hline 30 & 0.835 & 1.000 & 0.835 & drs & 0.835 & 1.000 & 0.835 & drs \\
\hline 31 & 0.475 & 0.796 & 0.597 & drs & 0.475 & 0.503 & 0.945 & irs \\
\hline 32 & 0.872 & 1.000 & 0.872 & drs & 0.872 & 1.000 & 0.872 & drs \\
\hline 33 & 0.422 & 0.838 & 0.504 & drs & 0.422 & 0.567 & 0.744 & drs \\
\hline 34 & 0.163 & 0.752 & 0.217 & drs & 0.163 & 0.230 & 0.710 & drs \\
\hline 35 & 0.582 & 0.608 & 0.956 & drs & 0.582 & 0.877 & 0.663 & irs \\
\hline 36 & 0.651 & 1.000 & 0.651 & drs & 0.651 & 1.000 & 0.651 & drs \\
\hline 37 & 0.199 & 0.563 & 0.353 & drs & 0.199 & 0.234 & 0.849 & irs \\
\hline 38 & 0.288 & 0.397 & 0.725 & drs & 0.288 & 0.582 & 0.495 & irs \\
\hline 39 & 1.000 & 1.000 & 1.000 & - & 1.000 & 1.000 & 1.000 & - \\
\hline 40 & 0.197 & 1.000 & 0.197 & drs & 0.197 & 1.000 & 0.197 & drs \\
\hline 41 & 0.080 & 0.202 & 0.394 & drs & 0.080 & 0.234 & 0.340 & irs \\
\hline 42 & 0.085 & 0.184 & 0.464 & drs & 0.085 & 0.203 & 0.421 & irs \\
\hline 43 & 0.021 & 0.149 & 0.140 & drs & 0.021 & 0.026 & 0.796 & irs \\
\hline 44 & 0.154 & 0.209 & 0.739 & drs & 0.154 & 0.473 & 0.326 & irs \\
\hline 45 & 0.423 & 0.586 & 0.722 & drs & 0.423 & 0.508 & 0.834 & irs \\
\hline 46 & 0.135 & 0.700 & 0.193 & drs & 0.135 & 0.156 & 0.865 & irs \\
\hline Mean & 0.305 & 0.580 & 0.480 & & 0.305 & 0.470 & 0.641 & \\
\hline Min & 0.021 & 0.087 & 0.132 & & 0.021 & 0.026 & 0.160 & \\
\hline Max & 1.000 & 1.000 & 1.000 & & 1.000 & 1.000 & 1.000 & \\
\hline
\end{tabular}


From the results in Table 1, it can be seen that under the output-orientated approach the district municipalities were, on average, only 30.5 per cent technically efficient under constant returns to scale, 58 per cent technically efficient under variable returns to scale, and 48.0 per cent scale efficient. According to the return to scale estimates (under the 'RETURN' column), all but two municipalities (i.e. district municipality numbers 15 and 39) were operating at decreasing returns to scale (DRS), which means that they were operating at a scale that was too large in efficiency terms.

Under the input-orientated approach, the district municipalities were, on average, 47.0 per cent technical efficient in the case of variable returns to scale, and 64.1 per cent scale efficient. With regard to the returns to scale, 32 municipalities were operating under increasing returns to scale (IRS), which necessarily implies that they were operating on a scale that was too small in efficiency terms. Only two district municipalities were operating at the optimal scale (i.e. district municipalities numbers 15 and 39), which means that they at the optimal size in efficiency terms. The remaining district municipalities were operating at decreasing returns to scale.

In the combined case of both the input-orientated and output-orientated approaches, 9 district municipalities (i.e. district municipalities numbers 11, 15, 23, 24, 30, 32, 36, 39 and 40) were fully technically efficient under variable returns to scale. This implies that these district municipalities were using their inputs optimally. Thus any reduction in the inputs employed by these municipalities will result in reduced output. The remaining district municipalities can either reduce their inputs without any reduction in output or expand their output without increasing their inputs.

We now consider the relative efficiency estimates obtained for individual local municipalities under the auspices of district municipalities. Given space constraints, only summary results from these estimations are provided in this paper. Table 2 displays the average efficiency as well as the minimum efficiency and maximum efficiency estimates for the best performing district municipality per province, according to the performance.

Table 2: Best-Performing District Municipality per Province

\begin{tabular}{|l|c|c|c|c|c|}
\hline \multirow{2}{*}{$\begin{array}{l}\text { Province/District } \\
\text { municipality }\end{array}$} & & \multicolumn{2}{|c}{ Output-orientated } & \multicolumn{2}{c|}{ Input-orientated } \\
\hline Western Cape/5 & Average & 0.618 & 0.690 & 0.618 & 0.736 \\
\hline & Min & 0.507 & 0.525 & 0.507 & 0.511 \\
\hline & Max & 0.775 & 0.914 & 0.775 & 0.934 \\
\hline Northern Cape/4 & Average & 0.744 & 0.753 & 0.744 & 0.756 \\
\hline & Min & 0.445 & 0.445 & 0.445 & 0.475 \\
\hline & Max & 1.000 & 1.000 & 1.000 & 1.000 \\
\hline East Cape/6 & Average & 0.698 & 0.732 & 0.698 & 0.741 \\
\hline & Min & 0.459 & 0.464 & 0.459 & 0.481 \\
\hline & Max & 0.937 & 1.000 & 0.937 & 1.000 \\
\hline Free State/1 & Average & 0.763 & 0.780 & 0.763 & 0.768 \\
\hline & Min & 0.659 & 0.660 & 0.659 & 0.659 \\
\hline & Max & 0.962 & 0.972 & 0.962 & 0.974 \\
\hline
\end{tabular}




\begin{tabular}{|l|c|c|c|c|c|}
\hline \multirow{2}{*}{$\begin{array}{l}\text { Province/District } \\
\text { municipality }\end{array}$} & & \multicolumn{2}{|c|}{ Output-orientated } & \multicolumn{2}{c|}{ Input-orientated } \\
\cline { 3 - 6 } Kwazulu/Natal/9 & Average & 0.707 & 0.759 & 0.707 & 0.786 \\
\hline & Min & 0.431 & 0.461 & 0.431 & 0.548 \\
\hline & Max & 1.000 & 1.000 & 1.000 & 1.000 \\
\hline Mpumalanga/3 & Average & 0.543 & 0.797 & 0.543 & 0.740 \\
\hline & Min & 0.404 & 0.618 & 0.404 & 0.511 \\
\hline & Max & 0.703 & 1.000 & 0.703 & 1.000 \\
\hline Limpopo/3 & Average & 0.795 & 0.878 & 0.795 & 0.856 \\
\hline & Min & 0.519 & 0.722 & 0.519 & 0.657 \\
\hline & Max & 1.000 & 1.000 & 1.000 & 1.000 \\
\hline Northwest/1 & Average & 0.536 & 0.801 & 0.536 & 0.748 \\
\hline & Min & 0.455 & 0.667 & 0.455 & 0.540 \\
\hline & Max & 0.660 & 1.000 & 0.660 & 1.000 \\
\hline Gauteng/3 & Average & 0.780 & 0.905 & 0.780 & 0.887 \\
\hline & Min & 0.598 & 0.853 & 0.598 & 0.827 \\
\hline & Max & 1.000 & 1.000 & 1.000 & 1.000 \\
\hline
\end{tabular}

In Table 2, district municipality 5 is the best performing local government in the Western Cape Province with an average efficiency estimate of 69.0 per cent (VRSTE) under the output-orientated approach and an average efficiency estimate of 73.6 per cent (VRSTE) under the input-orientated approach. More generally, efficiency estimates ranged between 52.5 per cent and 91.4 per cent under the output-orientated approach and between $51.1 \%$ per cent and 93.4 per cent under the input-orientated approach. None of the local municipalities operating under the auspices of this district municipality was fully technically efficient.

The Free State is the only other province in which its most efficient district municipality had none of its local municipalities operating at full technical efficiency. The average technical efficiency estimate under the output-orientated approach was 78.0 per cent and 76.8 per cent under the input-orientated approach. In terms of the output-orientated approach, the efficiency estimates ranged between 66.0 per cent and 97.2 per cent. By contrast, under the input-orientated approach, estimates ranged between 65.9 per cent and 97.4 per cent.

In the remaining seven South African provinces, there were a number of district municipalities which encompassed local municipalities which were fully technical efficient. District Municipality 3 in the Gauteng Province exhibited the highest average technical efficiency estimate (i.e. 90.5 per cent under the output-orientated approach and 88.7 per cent under the input-orientated approach).

Table 3 exhibits the worst performing district municipalities per province. District Municipality 5 in the Northern Cape had the lowest average efficiency estimate. Under the output-orientated approach, its average efficiency estimate was 40.7 per cent and under the input-orientated approach it was 36 per cent. In general, the efficiency estimate for this district municipality ranged between 16.6 per cent and 60.0 per cent. 
Table 3: Worst-Performing District Municipality per Province

\begin{tabular}{|c|c|c|c|c|c|}
\hline \multirow{2}{*}{$\begin{array}{l}\text { Province/District } \\
\text { municipality }\end{array}$} & & \multicolumn{2}{|c|}{ Output-orientated } & \multicolumn{2}{|c|}{ Input-orientated } \\
\hline & & CRSTE & VRSTE & CRSTE & VRSTE \\
\hline \multirow[t]{3}{*}{ Western Cape/4 } & Average & 0.456 & 0.517 & 0.468 & 0.489 \\
\hline & Min & 0.354 & 0.380 & 0.361 & 0.372 \\
\hline & Max & 0.672 & 0.689 & 0.617 & 0.665 \\
\hline \multirow[t]{3}{*}{ Northern Cape/5 } & Average & 0.368 & 0.447 & 0.368 & 0.412 \\
\hline & Min & 0.136 & 0.245 & 0.136 & 0.211 \\
\hline & Max & 0.695 & 0.726 & 0.695 & 0.753 \\
\hline \multirow[t]{3}{*}{ East Cape/5 } & Average & 0.328 & 0.407 & 0.328 & 0.362 \\
\hline & Min & 0.154 & 0.166 & 0.154 & 0.173 \\
\hline & Max & 0.538 & 0.600 & 0.538 & 0.542 \\
\hline \multirow[t]{3}{*}{ Free State/5 } & Average & 0.587 & 0.694 & 0.587 & 0.654 \\
\hline & Min & 0.527 & 0.620 & 0.527 & 0.577 \\
\hline & Max & 0.676 & 0.804 & 0.676 & 0.759 \\
\hline \multirow[t]{3}{*}{ Kwazulu/Natal/10 } & Average & 0.591 & 0.609 & 0.591 & 0.623 \\
\hline & Min & 0.388 & 0.399 & 0.388 & 0.485 \\
\hline & Max & 0.838 & 0.849 & 0.838 & 0.854 \\
\hline \multirow[t]{3}{*}{ Mpumalanga/1 } & Average & 0.529 & 0.643 & 0.529 & 0.586 \\
\hline & Min & 0.396 & 0.480 & 0.396 & 0.397 \\
\hline & Max & 0.644 & 0.812 & 0.644 & 0.752 \\
\hline \multirow[t]{3}{*}{ Limpopo/4 } & Average & 0.519 & 0.597 & 0.519 & 0.560 \\
\hline & Min & 0.315 & 0.387 & 0.315 & 0.315 \\
\hline & Max & 0.709 & 0.827 & 0.709 & 0.768 \\
\hline \multirow[t]{3}{*}{ Northwest/4 } & Average & 0.594 & 0.706 & 0.594 & 0.695 \\
\hline & Min & 0.407 & 0.459 & 0.407 & 0.463 \\
\hline & Max & 0.795 & 1.000 & 0.795 & 1.000 \\
\hline \multirow[t]{3}{*}{ Gauteng/1 } & Average & 0.510 & 0.670 & 0.510 & 0.620 \\
\hline & Min & 0.373 & 0.454 & 0.373 & 0.373 \\
\hline & Max & 0.669 & 1.000 & 0.669 & 1.000 \\
\hline
\end{tabular}


In Table 3, it is interesting to note is that although District 4 in the North West Province and District 1 in Gauteng Province were included in the list of worst performers, both had local municipalities that were fully technically efficient. This means that there were local municipalities that were using their inputs optimally even in the worst-performing district municipalities. Table 4 displays the average efficiency estimates of all the local municipalities per province.

Table 4: Average Efficiency Estimates of Local Municipalities per Province

\begin{tabular}{|c|c|c|c|c|c|}
\hline \multirow{2}{*}{$\begin{array}{l}\text { Province/District } \\
\text { municipality }\end{array}$} & & \multicolumn{2}{|c|}{ Output-orientated } & \multicolumn{2}{|c|}{ Input-orientated } \\
\hline & & CRSTE & VRSTE & CRSTE & VRSTE \\
\hline \multirow[t]{3}{*}{ Western Cape } & Average & 0.469 & 0.552 & 0.469 & 0.508 \\
\hline & Min & 0.354 & 0.380 & 0.354 & 0.355 \\
\hline & $\operatorname{Max}$ & 0.775 & 0.914 & 0.775 & 0.934 \\
\hline \multirow{2}{*}{$\begin{array}{l}\text { Province/District } \\
\text { municipality }\end{array}$} & & \multicolumn{2}{|c|}{ Output-orientated } & \multicolumn{2}{|c|}{ Input-orientated } \\
\hline & & CRSTE & VRSTE & CRSTE & VRSTE \\
\hline \multirow[t]{3}{*}{ Northern Cape } & Average & 0.589 & 0.624 & 0.589 & 0.646 \\
\hline & Min & 0.136 & 0.245 & 0.136 & 0.211 \\
\hline & $\operatorname{Max}$ & 1.000 & 1.000 & 1.000 & 1.000 \\
\hline \multirow[t]{3}{*}{ Eastern Cape } & Average & 0.512 & 0.569 & 0.512 & 0.554 \\
\hline & Min & 0.154 & 0.166 & 0.154 & 0.173 \\
\hline & $\operatorname{Max}$ & 0.937 & 1.000 & 0.937 & 1.000 \\
\hline \multirow[t]{3}{*}{ Free State } & Average & 0.624 & 0.724 & 0.624 & 0.701 \\
\hline & Min & 0.435 & 0.450 & 0.435 & 0.436 \\
\hline & Max & 0.962 & 1.000 & 0.962 & 1.000 \\
\hline \multirow[t]{3}{*}{ Kwazulu/Natal } & Average & 0.619 & 0.673 & 0.619 & 0.676 \\
\hline & Min & 0.315 & 0.358 & 0.315 & 0.361 \\
\hline & $\operatorname{Max}$ & 1.000 & 1.000 & 1.000 & 1.000 \\
\hline \multirow[t]{3}{*}{ Mpumalanga } & Average & 0.558 & 0.722 & 0.558 & 0.678 \\
\hline & Min & 0.396 & 0.464 & 0.396 & 0.397 \\
\hline & Max & 0.773 & 1.000 & 0.773 & 1.000 \\
\hline \multirow[t]{3}{*}{ Limpopo } & Average & 0.624 & 0.750 & 0.624 & 0.714 \\
\hline & Min & 0.300 & 0.387 & 0.300 & 0.315 \\
\hline & $\operatorname{Max}$ & 1.000 & 1.000 & 1.000 & 1.000 \\
\hline \multirow[t]{3}{*}{ Northwest } & Average & 0.607 & 0.755 & 0.607 & 0.721 \\
\hline & Min & 0.406 & 0.459 & 0.406 & 0.406 \\
\hline & Max & 1.000 & 1.000 & 1.000 & 1.000 \\
\hline \multirow[t]{3}{*}{ Gauteng } & Average & 0.677 & 0.794 & 0.677 & 0.767 \\
\hline & Min & 0.373 & 0.454 & 0.373 & 0.373 \\
\hline & Max & 1.000 & 1.000 & 1.000 & 1.000 \\
\hline
\end{tabular}

Table 4 shows that eight out of the nine South African provinces had one or more local municipality that was fully technically efficient. Only the Western Cape had no local municipality that was fully technically efficient. The Gauteng Province had the highest average efficiency estimate of 79.4 per cent under the output-orientated approach and 76.7 per cent under the input-orientated approach. The Western Cape was the worst-performing province with an average efficiency estimate of 55.25 per cent under the outputorientated approach and 50.8 per cent under the input-orientated approach. There are thus noteworthy inter-provincial differences in the relative efficiencies of local municipalities. 


\section{Concluding remarks}

The results obtained from this first preliminary attempt at measuring relative efficiency in South African local government should be regarded with caution mainly because the data from which they were derived are questionable. It would have been preferable to employ data provided directly from a large sample of district municipalities and local municipalities. However, since this proved impossible, we were obliged to use the only available data. Future research into the efficiency measurement of South African local government should seek to construct data from reliable sources.

Nonetheless, because there is no compelling a priori reason to assume that systematic differences in data reliability between provinces or between municipalities, from a policy perspective it is still possible to draw at least some useful tentative conclusions from our preliminary results. In the first place, as we have seen from the results in Table 4, considerable variation exists in the average efficiency scores between some provinces. This suggests that the financial and technical support for local government provided by the National Treasury to local government, which includes policy advice and the placement of international advisors in municipalities, should be more carefully targeted between the different provinces, and biased towards the worst-performing provinces. Secondly, because significant variation in efficiency also occurs within the constellation of municipalities in any given province, a closely related policy option would be to direct available resources to the worst-performing municipalities within each province.

\section{References}

African National Congress (1994), The Reconstruction and Development Programme: A Policy Framework, Umanyano Publications, Johannesburg.

Atkinson, D. (2002), Local Government, Local Governance and Sustainable Development, HSRC Press, Pretoria.

Bahl, R. and Smoke, P. (eds.) (2003), Restructuring Local Government Finance in Developing Countries: Lessons from South Africa, Edward Elgar Publishers, Cheltenham.

Buthelezi, A. and Dollery, B. E. (2004), "An Exploratory Analysis of Local Government Failure in South Africa", Studies in Economics and Econometrics, 28(2), 91-105.

Cameron, R. (2001), “The Upliftment of South African Local Government", Local Government Studies, 27(3), 97-118.

Coelli, T. (1996), "A Guide to DEAP Version 2.1 Data Envelopment Analysis (Computer) Program", Centre for Productivity Analysis Working Paper 96/07, Department of Econometrics, University of New England, Armidale.

Coelli, T., Rao, D.S.P. and Battese, G. (1998), An Introduction to Effciency and Productivity Analysis, Kluwer Academic Publishers, Boston.

Dollery, B. E. (2003), "A History of Inequality in South Africa: Review Note", South African Journal of Economics, 71(3), 595-610. 
Dollery, B. E., Crase, L. and Marshall, N. A. (2005), "The Economic Case for Virtual Local Government in South Africa", Studies in Economics and Econometrics, 29(1), 47-60.

Dollery, B. E., Garcea, J. and LeSage, E. (2008), Local Government Reform, Edward Elgar Publishers, Cheltenham.

Dollery, B. E. and Graves, N. (2009), "Funding Compliance Measurement to Understand Best-Practice Financial Management Technical Assistance to South African Local Government", Public Administration and Development, 29(1), 101-116.

Dollery, B. E. and Snowball, J. (2003), "Government Failure and State Incapacity: The South African Public Sector in the 1990", South African Journal of Economic History, Special Issue, 18(1/2), 310-331.

Graves, N. and Dollery, B. E. (2009), "Local Government Reform in South Africa: An Analysis of Financial Management Legislative Compliance by Municipalities", Public Administration and Development, 29(5), 387-414.

Lester, A., Nel, E. and Binns, T. (2000), South Africa: Past, Present and Future, Longman, Harlow.

McDonald, D. A. and Pape, J. (eds.), (2002), Cost Recovery and the Crisis of Service Delivery in South Africa, HSRC Press, Pretoria.

Miraftab, F. (2004), "Neoliberalism and Casualization of Public Services: Waste Collection Services in Cape Town, South Africa", International Journal of Urban and Regional Research, 28(4), 874892.

Municipal Demarcation Board. 2007, Capacity Assessments 2006/2007, http://www demarcation.org.za (Date accessed - various occasions).

Nel, E. and Binns, T. (2002), "Devolving Development: Integrated Local Planning and Developmental Local Government in post-Apartheid South Africa”, Regional Studies, 36(8) 921-945.

Republic of South Africa (1998), White Paper on Local Government, Department of Constitutional Development, Pretoria.

Stats SA. 2008, Mid-year population estimates 2008 - Series P0302, http://www. statssa.gov.za/publications/populationstats.asp (Date accessed: various occasions).

Visser, G. (2001), "Social Justice, Integrated Development Planning and Post-Apartheid urban Reconstruction", Urban Studies, 38(10), 673-699.

Worthington, A. C. (2001), "The Empirical Measurement of Local Government Efficiency”, in B. E. Dollery and J. L. Wallis, The Political Economy of Local Government, Edward Elgar Publishers, Cheltenham.

Worthington, A. C. and Dollery, B. E. (2000), "Measuring Efficiency in Local Government", Public Productivity and Management Review, 23(4), 469-485.

Worthington, A. C. and Dollery, B. E. (2002), "Incorporating Contextual Information in Public Sector Efficiency Analysis: A Comparative Study of NSW Local Government”, Applied Economics, 34(3), 453-464. 